\title{
Two new species of Caulleriella (Polychaeta, Cirratulidae) from Argentina
}

\author{
Rodolfo Elías \& María S. Rivero
}

Departamento de Ciencias Marinas, Universidad Nacional de Mar del Plata, Deán Funes 3350, B 7602 AYL, Mar del Plata, Argentina. (roelias@mdp.edu.ar)

\begin{abstract}
Caulleriella bremecae and C. galeanoi (Polychaeta: Cirratulidae) are newly described from Mar del Plata, Argentina ( $38^{\circ}$ S, $57^{\circ} \mathrm{W}$ ). Both species have small, red-pigmented nuchal organs (lateral "eyes") on the prostomium. Caulleriella bremecae sp. nov. is further characterized by a peristomium without annulations except for a narrow anterior dorsal fold, posterior part of peristomium extending posterodorsally over chaetiger 1, latter extending posterodorsally over chaetiger 2 and with slightly separated grooved palps arising middorsally; notochaetae of chaetigers 1-23 all smooth capillaries, thereafter with six bidentate sigmoid hooks and 3-4 capillaries, both types fewer on last 4-5 chaetigers; neurochaetae of chaetigers 1-2 comprised of 8 bidentate hooks and 1-2 capillaries, thereafter only bidentate hooks, decreasing in number posteriorly. The species is frequent and abundant throughout the year in the intertidal mussel beds situated 200-700m from the sewage outfall of Mar del Plata city. Caulleriella galeanoi sp. nov. is characterized by a peristomium with three annulations dorsally, with grooved palps arising from annulus 3, and by smooth capillary chaetae in noto- and neuropodia of chaetigers 1-2. Bidentate hooks are present in neuropodia from chaetiger 3, numbering 5-6 in anterior and middle chaetigers, 1-3 in posterior ones. Notopodia have 3-6 pairs of smooth capillary chaetae, decreasing in number posteriorly. From chaetiger 13-20, notopodia with 1-2 capillary chaetae and 1-2 bidentate hooks. Specimens held in aquaria supplied with water and the green alga Vaucheria sp. (Vaucheriaceae) from the intertidal zone reproduced asexually by fission. Gametes were not observed in any specimens.
\end{abstract}

KEYWORDS. Polychaeta, Cirratulidae, Caulleriella new species, Mar del Plata, Argentina.

RESUMO. Duas novas espécies de Caulleriella (Polychaeta, Cirratulidae) da Argentina. As espécies novas Caulleriella bremecae e C. galeanoi (Polychaeta: Cirratulidae) são descritas para a região de Mar del Plata, Argentina $\left(38^{\circ} \mathrm{S}, 57^{\circ} \mathrm{W}\right)$. Ambas têm pequenos órgãos nucais prostomiais de cor vermelha. Cauleriella bremecae sp. nov. é diagnosticada pela presença de peristômio sem anelações, com exceção de uma estreita dobra antero-dorsal; parte posterior do peristômio projetando-se posterodorsalmente sobre o setígero 1 , que por sua vez se estende sobre a metade antero-dorsal do setígero 2; setígero 1 com palpos sulcados, em posição médio-dorsal, ligeiramente separados entre si; notocerdas dos setígeros 1-23 todas capilares lisas, substituídas a seguir por 6 ganchos sigmóides bidentados e 3-4 capilares, em menor número nos 4-5 últimos setígeros; neurocerdas dos setígeros 1-2 incluem 8 ganchos bidentados e 1-2 capilares, a seguir apenas ganchos bidentados, cujo número decresce posteriormente. A espécie é constante (?) e abundante ao longo de todo o ano em bancos de mexilhões na região entre marés, a 200-700 metros do ponto de despejo do duto de esgotos de Mar del Plata. Caulleriella galeanoi sp. nov. é diagnosticada por um peristômio com 3 anelações dorsais, com palpos sulcados inseridos na terceira anelação; cerdas capilares lisas nos notopódios e neuropódios dos setígeros 1-2; 5-6 ganchos bidentados neuropodiais a partir do setígero 3, diminuindo para 1-3 nos setígeros posteriores; notopódios anteriores com 3-6 pares de cerdas capilares lisas, presentes em menor número nos notopódios posteriores. A partir dos setígeros 13-20, notopódios com 1-2 cerdas capilares e 1-2 ganchos bidentados. Exemplares mantidos em aquários com a clorofícea Vaucheria sp reproduziram-se assexuadamente por fissão. Não foram observados gametas.

PALAVRAS-CHAVE. Polychaeta, Cirratulidae, Caulleriella novas espécies, Mar del Plata, Argentina.

Although several faunistic and other studies on polychaetes have been published during the last half century, many regions still lack taxonomic knowledge about the local fauna. This is particularly true for Argentina, whose extensive coastline spans more than $4,000 \mathrm{~km}$. The first characterization of macrobenthic communities from the extensive Argentine shelf did not include polychaetes due to "insufficient taxonomic knowledge, although [Polychaeta] is a relatively abundant group" (BAstida et al., 1992). Among Argentine polychaetes, members of Cirratulidae Ryckholt, 1851 are particularly undocumented.

Cirratulids belong to the subclass Palpata, order Canalipalpata, suborder Terebellida. The family includes organisms with cylindrical body, with a blunt or conical prostomium, and reduced parapodia. Feeding palps arise dorsally in many species, but others have only tentacular cirri. Slender filiform branchiae are present on at least some chaetigers. Chaetae are mostly capillary, but curved or excavate hooks are characteristic of some genera
(FAuchald, 1977). Chaetal morphology is the main diagnostic character at the generic and specific levels (Hartman, 1961; BlaKe, 1996), but chaetal morphology may vary throughout ontogeny, requiring special care in taxonomic identification (GEORGE \& PETERSEN, 1991).

This is the first of a planned series of contributions destined to elucidate the taxonomic status and diversity of Argentine cirratulids. Starting in 1996, and at the request of the Mar del Plata city water management authority (Obras Sanitarias Sociedad de Estado, OSSE), a series of benthic studies were conducted in intertidal and subtidal areas affected by sewage discharge. These studies were performed in order to obtain baseline information before the construction of a new sewer that will discharge wastes up to $3 \mathrm{~km}$ offshore ( $11 \mathrm{~m}$ depth), replacing the current one that discharges in the intertidal zone. These ecological studies have improved the knowledge of the regional polychaete fauna (e. g., ElíAs \& BREMEC, 1997, 2003; Elías et al., 2001, 2003a, b; Elias, 2002; VALLARINO et al., 2002; Rivero et al., 2005). 
We describe herein two new species of the genus Caulleriella Chamberlin, 1919, one of which was previously identified as Caulleriella alata (Southern, 1914).

\section{MATERIAL AND METHODS}

The study area, around Mar del Plata (Buenos Aires Province, $38^{\circ} \mathrm{S}, 57^{\circ} \mathrm{W}$ ), is located within the boundaries of the Argentine Biogeographic Province (warm-temperate region of the southwestern Atlantic) (BosCHI, 2000).

Samples were obtained from intertidal beds of the small mytilid Brachidontes rodriguezii (d'Orbigny, 1846), around the sewage outfall. Several stations were sampled since 1997 by means of replicate $78 \mathrm{~cm}^{2}$ corers; materials were sieved through $1 \mathrm{~mm}$ mesh (VALLARINO et al., 2002; ELíAs et al., 2003a, 2006).

During a series of laboratory experiments, one aquarium, supplied with seawater from the intertidal zone, developed an algal cover of Vaucheria sp. Associated with the latter we observed specimens of Caulleriella. Observations with light microscopes and scanning electron microscope (SEM) showed it to be different from the one collected in the mussel beds.

Specimens of both species were examined with a JEOL (JSM - 6460 LV) scanning electron microscope. Materials for SEM were fixed for $24 \mathrm{~h}$ with glutaraldehyde $3 \%$ in a buffer solution of sodium cacadylate $0.1 \mathrm{~mol}, \mathrm{pH}$ between 7.2-7.4, then dehydrated in ETOH (50, 70, 80, 90 , 95 and 100\%). Samples were dried in hexamethyldisilazane (HMDS), mounted on aluminum discs and coated with Au-Pd (Gold-Palladium). Small specimens were mounted on slides with a Grey \& Wess Medium (PVA: polyvinyl alcohol) for optical observation.

All materials were deposited in the Museo de Ciencias Naturales de La Plata (MCNLP), Argentina.

The genus Caulleriella is characterized by an elongated prostomium, and a short or long peristomium; two grooved tentacules anterior to chaetiger 1; middle segments not beaded; noto- and neuropodia widely separated, with a large gap between them. Chaetae include capillaries and bidentate, crotchetlike hooks, not arranged in cinctures (BLAKE, 1996).

The species of Caulleriella are still very incompletely known. Caulleriella alata, originally described from Ireland, has been reported from southern Argentina (ORENSANZ, 1974), southeast Brazil (Bolivar, 1990), Chile (including a subspecies $C$. alata chilensis Carrasco, 1977) to Gulf of Mexico and Florida (Wolf, 1984), Massachusetts (Hartman, 1965) and California (HARTMAN, 1961) in USA. This distribution is not coherent, and further studies will very likely show that this "group" consists of several species. Most Southern Hemisphere cirratulid species should be reviewed.

\section{Caulleriella bremecae sp. nov.} (Figs. 1-6)

Caulleriella alata: ElíAs, 2002; ElíAs et al., 2003a: table 1; Rivero et al., 2005: table 1 (non Southern, 1914).

Etymology. The species is dedicated to Dr. Claudia S. Bremec, polychaetologist who shares our passion for the study of worms from the Argentine sea.
Description. A moderate-size species. Body elliptical; chaetigers widest at mid-body, roughly square in cross section throughout; ventral surface concave to pygidium (Fig. 1). Color in alcohol yellowish-tan.

Prostomium triangular in dorsal and lateral views, as wide as long and with very irregular epidermis, appearing glandular. Prostomium with lateral "red eyespots", which under SEM look like vertical depressions; these are in fact ciliated nuchal organs (Fig. 2) (DONER \& BlAKE, 2006). Peristomium achaetous, lacking annulations, except for a narrow dorsal annulus. Dorsal part of peristomium extending over half of chaetiger 1 and forming slightly raised crest (Figs. 1, 4); grooved palps slightly separated, arising medially from posterior part of chaetiger 1; latter overlapping anterior half of chaetiger 2. First pair of filiform branchiae present on chaetiger 1, anterior and lateral to palps; subsequent pairs of branchiae on each following segment slightly dorsal to notochaetae (Fig. 3), frequent and long in anterior segments, shorter and less frequent in middle ones, absent on posterior ones.

Notopodia with 8-10 long and short capillary chaetae on first 23 chaetigers; subsequent chaetigers with six bidentate sigmoid hooks and with 3-4 capillary chaetae; last 4-5 chaetigers with fewer hooks and some capillary chaetae. Hooks without hood or wing, with unequal teeth (Fig. 5). Neuropodia of chaetigers 1-2 (exceptionally 1-3) with 6-9 bidentate hooks and 1-2 capillary chaetae; hooks decreasing in number (down to 3 ) posteriorly. Pygidium rounded, with dorsal anus (Fig. 6).

Methyl Green Staining Pattern. Prostomium, palps and branchiae well stained. Staining darker ventrally, mostly on anterior neuropodia.

Remarks. Caulleriella bremecae differs from $C$. alata in the position of the eyespots, which are dorsal, versus lateral in our material. Caulleriella alata has a simple peristomium not overlapping chaetiger 1 , and with first pair of branchiae lateral to palps and on posterior part of peristomium, while in C. bremecae the peristomium forms a slight crest and overlaps chaetiger 1; the first pair of branchiae arises anterolaterally with respect to the palps, with both arising from posterior part of chaetiger 1. Caulleriella alata has long and short capillaries to the last notopodium, with the shorter capillaries being distinctly flattened, while $C$. bremecae lacks notochaetae in posteriormost chaetigers. Neuropodia bear hooks and capillaries on all segments in C. alata, while only a few capillaries are present on the first two (rarely three) neuropodia in $C$. bremecae. Caulleriella alata has bidentate hooks with a distinct wing on the convex side of the shaft above the constriction and only a slight bend distally; whereas hooks of $C$. bremecae have no wing (or hood), lack the constriction and are bent at a nearly right angle (Fig. 5).

DeAn \& BlaKe (2007) described $C$. moralesensis and also compared it with $C$. alata. The former species is larger and with more segments than $C$. bremecae, and only the anterior region is flattened dorsoventrally, while in $C$. bremecae all the body is flattened dorsoventrally. The peristomium of $C$. moralesensis is triannulated, with 

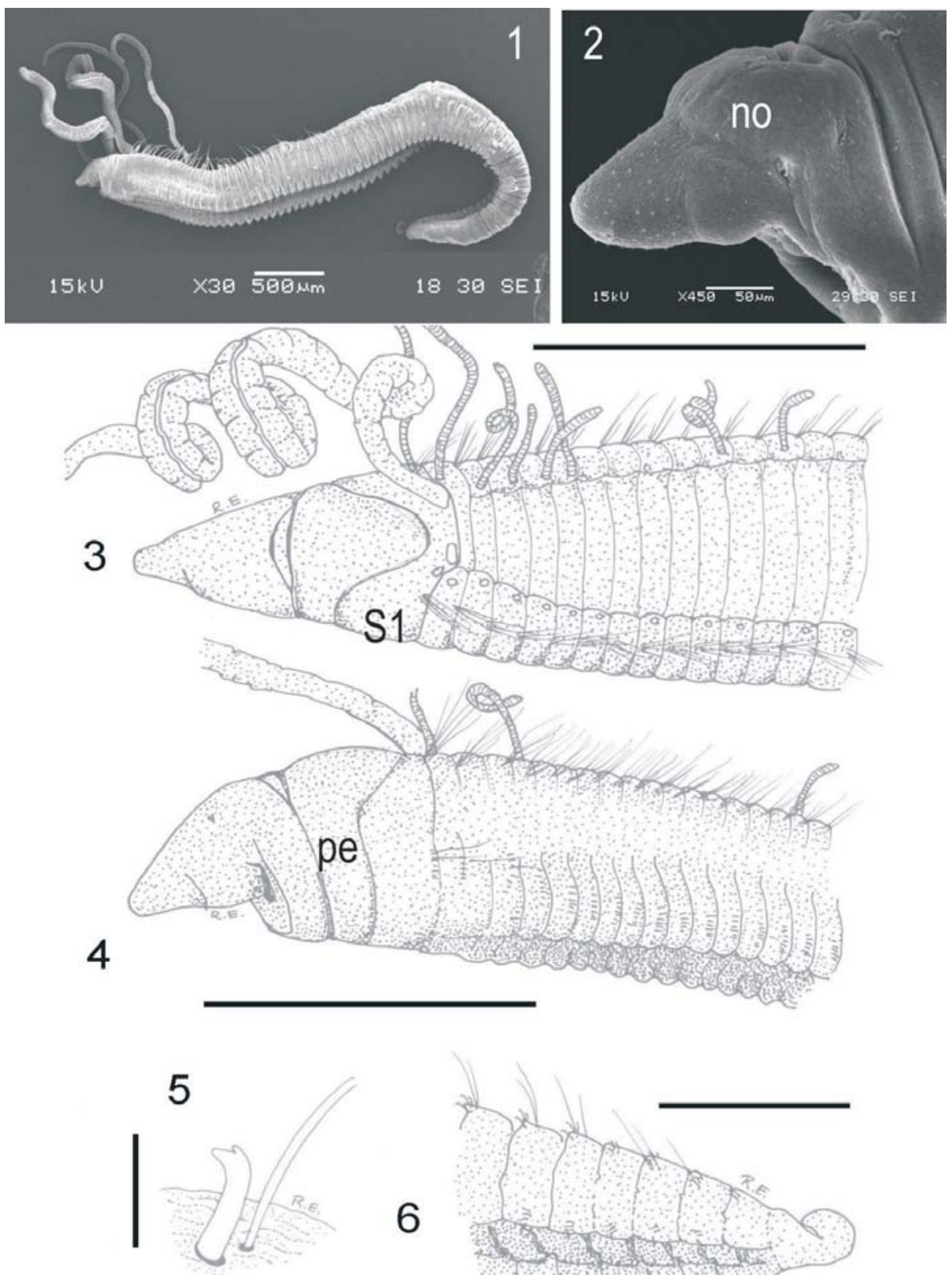

6

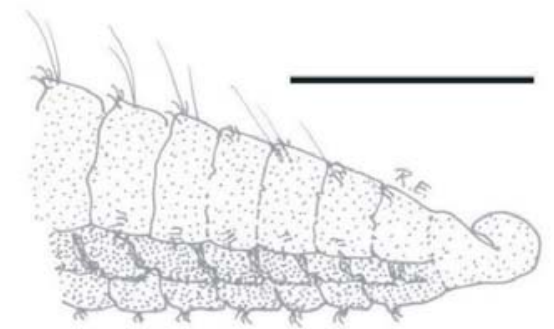

Figs. 1-6. Caulleriella bremecae sp. nov. 1, left lateral view of complete specimen (SEM); 2, anterior end of another specimen showing location of ciliated nuchal organ; 3, anterior end in dorsal view; 4, same specimen, left lateral view; 5, drawing of bidentate hook and companion capillary; 6, posterior end and pygidium, left ventrolateral view (no, nuchal organ; pe, peristomium; S1, segment 1). Scale

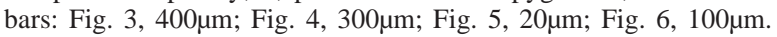

the first annulus covering partially the prostomium, while in $C$. bremecae the peristomium lacks annulations and the crest partially covers chaetiger 1 ; nuchal organs are rounded in $C$. moralesensis and vertical slits in $C$. bremecae; the pygidium is a rounded lobe in both species, but the anus is ventral in $C$. moralesensis and dorsal in C. bremecae; notopodial hooks starting in the same chaetiger (23), but the neurochaetal pattern differs.

Distribution. Caulleriella bremecae is only known from off Mar del Plata.

Ecology. The species has been observed in the intertidal zone. It is associated with the sediments retained by the beds of the small mussel $B$. rodriguezii in areas moderately enriched by sewage discharge around Mar del Plata. Control sites and most impacted areas had only occasional records and low abundance.

Material examined. Mar del Plata, near the intertidal sewage discharge: $37^{\circ} 55.591^{\prime} \mathrm{S}, 57^{\circ} 31.701^{\prime} \mathrm{W}$; station $2(230 \mathrm{~m}$ from outfall; November 1997, 6 specimens; March 1998, 2 specimens; August 1998, 3 specimens); station 3 (450m from outfall, November 1997, 3 specimens); station 4 (700m from outfall, November 1997, 7 specimens). Additional material: 20 specimens examined with SEM and 7 slides.

Type material. ARGENTINA, Mar del Plata: intertidal. Holotype (MCNLP 6338) - 8.1mm long and $0.62 \mathrm{~mm}$ across thoracic region for approximately 70 chaetigers. Paratypes: (MCNLP 6339, 10 specimens). 


\section{Caulleriella galeanoi sp. nov.}

(Figs. 7-10)

Etymology. This species is named in honor of Eduardo Galeano, Uruguayan author.

Description. Very small species (Fig. 7). Body short; noto- and neuropodia widely separated (Fig. 9); ventral surface grooved from chaetiger 1, dorsum grooved from chaetiger 4-5. Color in life yellowish-tan with brown dots, latter denser on the dorsal surface, palps and some branchiae; pygidium densely pigmented, almost black. Color pattern remains after organisms are fixed in formaldehyde solution and transferred to ETOH. Specimens fixed in ETOH turn green, becoming gray shortly after.

Prostomium short and rounded, with irregular epidermis; laterally, with a pair of rounded red spots resembling eyes (Fig. 9). Close SEM examination revealed that those structures are nuchal organs (Fig. 8). Peristomium slightly annulated dorsally; first two annuli wide, but third annulus narrow and bearing a pair of long, grooved palps; first pair of branchiae lateral to dorsal tentacles and anterior to chaetiger 1; branchiae long and thin, present through most of body length, only absent
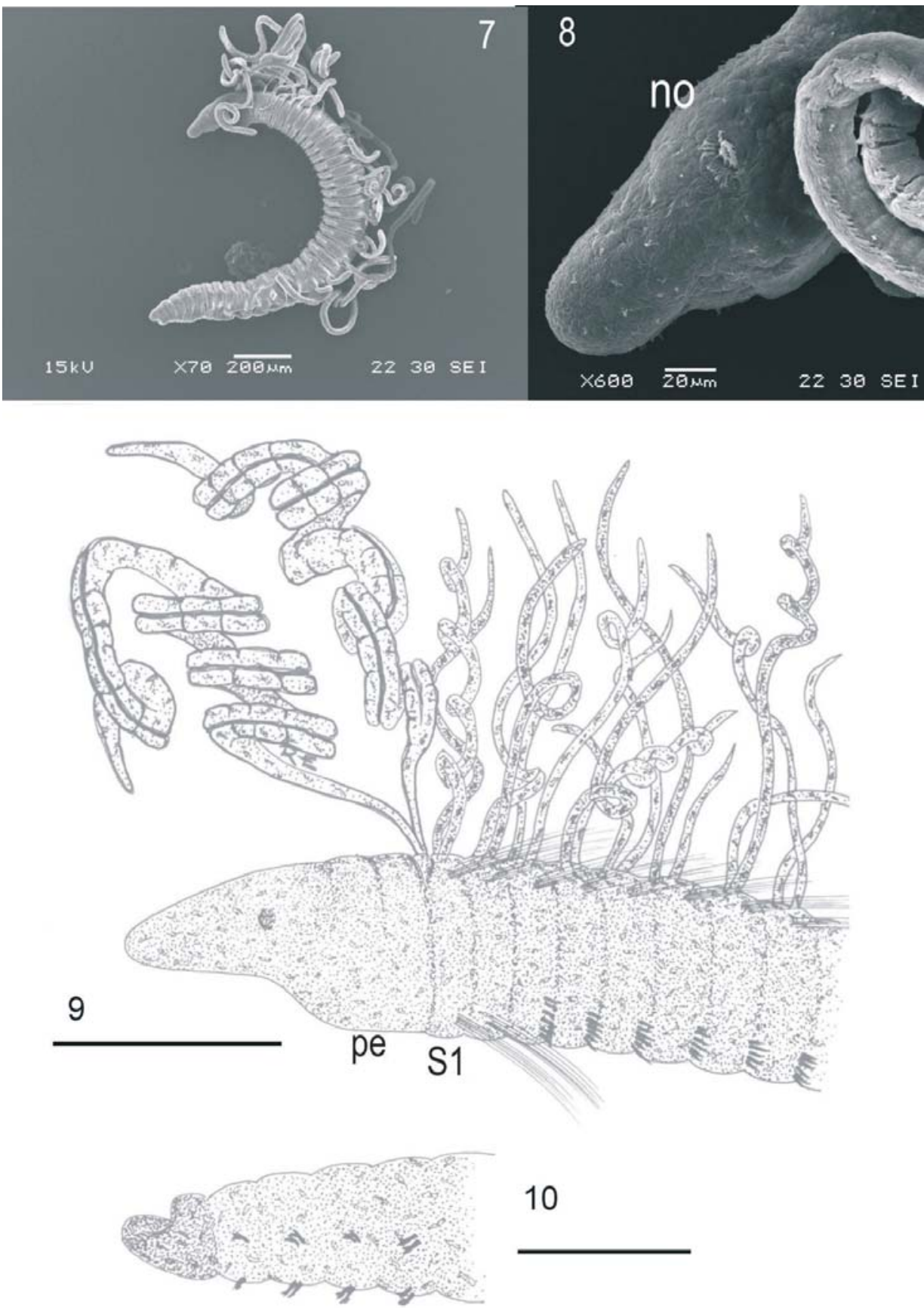

10

Figs. 7-10. Caulleriella galeanoi sp. nov.: 7, left lateral view of complete specimen (SEM); 8, left lateral view of prostomium showing ciliated nuchal organ (SEM); 9, left lateral view of anterior end showing pigmentation pattern on body, palps and branchiae; 10, right dorsolateral view of posterior end and pygidium (no, nuchal organ; per, peristomium; S1, segment 1). Scale bars: Fig. 9, $150 \mu \mathrm{m}$; Fig. 10, $150 \mu \mathrm{m}$. 
on posteriormost chaetigers; dorsal tentacles thick and grooved.

Notopodia with simple capillaries, arranged in fascicules of 2-4 pairs; bidentate hooks first present from chaetigers 21 in holotype, and between 8 to 22 in paratypes; 2-3 hooks at first, with 1-2 capillaries between hooks. Neuropodia with 1-2 simple capillaries in chaetigers 1-2; bidentate hooks starting on chaetiger 3 , numbering 5-6 per neuropodium on anterior and middle chaetigers, dropping to 1-4 on posterior ones. No accompanying capillary chaetae. Hooks with apical tooth curved, varying from one-third to same length as main fang; no hood. Pygidium rounded, with dorsal anus (Fig. 10).

Methyl Green Staining Pattern. There is no clear staining pattern. Only palps and some branchiae stained slightly. Parts that are in the process of schizometamery stained darker, as well as the pygidium.

Remarks. Caulleriella galeanoi is closely similar to C. bioculata (Keferstein, 1862) but differs markedly in having a simple pygidium instead of the bilobed pygdium present in C. bioculata. Since the two lobes are not anal cirri, which may be lost, they will be present on any but incomplete specimens. Both species have a rounded prostomium, and are similar in the shape of the peristomium and position of palps and branchiae; they have notopodial capillaries all along the body, notopodial bidentate hooks are absent from a variable number of anterior chaetigers, neuropodial capillaries are present on chaetigers 1-2, and neuropodial bidentate hooks from chaetiger 3 to the posterior end. The two species differ in that the capillaries are simple in $C$. galeanoi but limbate and pectinate in $C$. bioculata; the peristomium is slightly triannulate dorsally in $C$. galeanoi but not in $C$. bioculata; notopodial hooks start on chaetiger 8-22 in C. galeanoi and in chaetiger 6-9 in C. bioculata. Complete specimens of $C$. galeanoi are quite short, $5 \mathrm{~mm}$ long for about 50 chaetigers, while $C$. bioculata can have more than 140 chaetigers and reach a length of $40 \mathrm{~mm}$. Pigmentation in C. galeanoi is clearly different due to the presence of granules of dark pigment.

Another similar species is C. minuta Dean \& Blake, 2007 (also confused with C. bioculata). Caulleriella galeanoi is similar to $C$. minuta in having small body size, small number of chaetigers, triannulate peristomium, neuropodium with capillaries in first chaetigers and hooks with no accompanying capillaries. However, in $C$. galeanoi the peristomium has a different annulation shape; neuropodia 1-2 have capillaries (three in $C$. minuta); and hooks have no capillaries; they are accompanied by capillaries in the anterior 4-9 chaetigers in $C$. minuta. Capillaries are laterally fimbriated in $C$. minuta and smooth in C. galeanoi, and the pattern of notopodial capillaries and hooks differs, as does the pigmentation.

An interesting feature of $C$. galeanoi and $C$. bremecae is the presence of nuchal organs resembling red eyespots. According to Doner \& Blake (2006), in Caulleriella species the nuchal organs are a longitudinal slit, whereas in examined Chaetozone species it is circular. These authors suggest that location and shape of nuchal organs may be important generic-level characters in some cirratulids. This generalization is not valid for the South
American C. bremecae, as nuchal organs here are as vertical slits. A comparative SEM study of cirratulid "eyes" is needed to reveal the real nature of these red- or black-pigmented structures (DONER \& BLAKE, 2006).

Distribution. Only known from the Mar del Plata area, in aquaria.

Ecology. This species was not recorded in natural habitats. Specimens were found in aquaria supplied with seawater from the intertidal zone. The aquaria developed mats of the alga Vaucheria sp., and the organisms preferred this habitat rather than the sediment of the bottom. The fact that specimens fixed in ETOH turn green suggests that they can be feeding on the algae, in spite of the deposit-feeding typical of cirratulids (FAUCHALD \& Jumars, 1979). In the course of our study, C. galeanoi reproduced only asexually, by schizometamery.

Type material. ARGENTINA, Mar del Plata: from aquaria supplied with water from the intertidal zone. Holotype (MCNLP $6340)-4.6 \mathrm{~mm}$ long and $0.05 \mathrm{~mm}$ wide across thoracic region for approximately 55 chaetigers; Paratypes: (MCNLP 6341, 20 specimens). Additional material examined: 18 specimens for SEM - 3 juveniles of 24-28 chaetigers and 15 adults with about 50 chaetigers, all immature - and 8 on slides. Additional material. Material fixed in $100 \%$ ethanol for molecular studies: MLP deposited as MCNLP 6342.

Acknowledgments. To Mary E. Petersen, who 'discovered' that our Cirratulus cirratus was not a C. cirratus, and triggered the present revision of Argentine cirratulids. She also made several corrections to the manuscript. Claudia Bremec (INIDEP, Mar del Plata), Lobo Orensanz (CENPAT, Puerto Madryn), Paulo Lana and Cinthya Gomes Santos (UFPR, Curitiba) provided references, ideas and friendship. Lobo Orensanz and Paulo Lana critically read the manuscript. Two referees suggested changes that improved the manuscript. The resumo was written by Paulo Lana. SEM images were obtained by Lic. Mónica Oppedisano from the Laboratorio de Microscopía Electrónica of Facultad de Ciencias Exactas y Naturales of the Universidad Nacional de Mar del Plata. Figures were drawn by RE. This study was supported by grant PICTO $2004 n^{\circ} 1-536$ (BID 1728/OCAR) from the Agencia Nacional de Promoción de Ciencia y Técnica and the Universidad Nacional de Mar del Plata.

\section{REFERENCES}

Bastida, R.; Roux, A. \& Martinez, D. 1992. Benthic communities of the Argentine continental shelf. Oceanologica Acta 16:687-698.

BlaKe, J. A. 1996. Family Cirratulidae Ryckholdt, 1851. Including a revision of the genera and species from the eastern North Pacific. In: Blake, J. A.; Hilbig, B. \& Scott, P. H. eds. Taxonomic Atlas of the Benthic Fauna of the Santa Maria Basin and the Western Santa Barbara Channel. Volume 6. The Annelida Part 3. Polychaeta: Orbiniidae to Cossuridae. Santa Barbara, Santa Barbara Museum of Natural History. p.263-384.

Bolivar, G. A. 1990. Orbiniidae, Paraonidae, Heterospionidae, Cirratulidae, Capitellidae, Maldanidae, Scalibregmidae e Flabelligeridae (Annelida: Polychaeta) da costa sudeste do Brasil (22 $57^{\prime}$ S - 2720'S). Tese de Doutorado. Universidade Federal do Paraná. Depto. de Zoologia. 191p.

Boschi, E. E. 2000. Species of decapod crustaceans and their distribution in the American marine zoogeographic provinces. Revista de Investigación y Desarrollo Pesquero 13:7-136.

Dean, H. K. \& Blake, J. A. 2007. Chaetozone and Caulleriella (Polychaeta: Cirratulidae) from the Pacific coast of Costa Rica, with description of eight new species. Zootaxa 1451:41-68.

Doner, S. A. \& Blake, J. A. 2006. New species of Cirratulidae (Polychaeta) from the northeastern United States. In: SARDA, R.; San Martin, G.; Lopez, E.; Martin, D. \& George, D. eds. Scientific advances on Polychaete research. Scientia Marina 70(3):65-73. 
ElíAs, R. 2002. Clave ilustrada para la identificación de poliquetos bonaerenses asociados a la comunidad intermareal del bivalvo Brachidontes rodriguezii (d’Orbigny, 1846). Neotropica 48:1-10.

Elías, R. \& Bremec, C. S. 1997. First record of Magelonidae, Magelona riojai Jones, 1963 (Polychaeta) in coastal waters of Argentina. Nerítica 11(1/2):111-117.

2003. First record of the genus Armandia (Polychaeta, Opheliidae) in coastal waters of Argentina, with the description of a new species Armandia loboi. Bulletin of Marine Science 72(1):181-186.

Elías, R.; Bremec, C. S. \& Vallarino, E. A. 2001. Polychaetes from a southwestern shallow shelf Atlantic area (Argentina $38^{\circ} \mathrm{S}$ ) affected by sewage discharge. Revista Chilena de Historia Natural 74(3):523-531.

Elías, R.; Rivero, M. S. \& Vallarino, E. A. 2003a. Sewage impact on the composition and distribution of Polychaeta associated to intertidal mussel beds of the Mar del Plata rocky shore, Argentina. Iheringia, Serie Zoologia, 93(3):309-318.

Elías, R.; Bremec, C. S.; Lana, P. C. \& Orensanz, J. M. 2003 b. Opheliidae (Polychaeta) from the southwestern Atlantic Ocean, with the description of Travisia amadoi n. sp., Ophelina gaucha $\mathrm{n}$. $\mathrm{sp}$. and Ophelina alata $\mathrm{n}$. $\mathrm{sp}$. Hydrobiología 496(1/3):75-85.

Elias, R.; Rivero, M. S.; Palacios, J. R. \& Vallarino, E. A. 2006 Sewage-induced disturbance on polychaetes inhabiting intertidal mussel beds of Brachidontes rodriguezii off Mar de Plata (Southwestern Atlantic, Argentina). In: SARDA, R.; SAN Martin, G.; Lopez, E.; Martin, D. \& George, D. eds. Scientific advances on Polychaete research. Scientia Marina 70(3): 187-196.

Fauchald, K. 1977. The Polychaete Worms. Definitions and Keys to Orders, Families and Genera. Natural History Museum of Los Angeles County \& The Allan Hancock Foundation, University of Southern California, Science Series 28:1-188.
Fauchald, K. \& Jumars, P. A. 1979. The diet of worms: a study of polychaete feeding guilds. Oceanography and Marine Biology Annual Review 17:193-284.

George, J. D. \& Petersen, M. E. 1991. The validity of the genus Zeppelina Vaillant (Polychaeta: Ctenodrillidae). In: Petersen, M. E. \& Kirkeganad, J. B. eds. Systematics, biology and morphology of World Polychaeta. Proceedings of the 2nd International Polychaete Conference, Copenhagen, 1986. Ophelia Supplement 5:9-100.

Hartman, O. 1961. Polychaetous annelids from California. Allan Hancock Pacific Expeditions 25:1-226.

1965. Deep-water benthic polychaetous annelids off New England to Bermuda and other North Atlantic areas. Allan Hancock Foundation Occasional Paper 28:1-378.

Orensanz, J. M. 1974. Los anélidos poliquetos de la Provincia biogeográfica Magallánica. I. Catálogo de las especies citadas hasta 1974. Laboratorio de Comunidades Bentónicas Gabinete abierto - Sta. Clara del Mar. Contribución Técnica 1:3-76.

Rivero, M. S.; Vallarino, E. A. \& Elías, R. 2005. First survey in

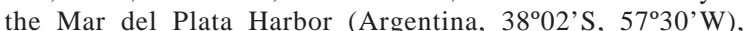
and the use of polychaetes as potential indicators of pollution. Revista de Biología Marina y Oceanografía 40(2): $101-108$

Vallarino, E. A.; Rivero, M. S.; Gravina, M. C. \& Elías, R. 2002. The community-level response to sewage impact in intertidal mussel beds of the Southwestern Atlantic, and the use of the Shannon index to assess pollution. Revista de Biología Marina y Oceanografía 37(1):25-33.

Wolf, P. S. 1984. Family Cirratulidae Carus, 1863. In: Ubelacker, J. M. \& Johnson, P. G. eds. Taxonomic guide to the polychaetes of the northern Gulf of Mexico. Final Report to the Minerals Management Service, contract 14-12-001-29091. Mobile, Barry A. Vittors. v.2, p.12-1$12-30$

Recebido em dezembro de 2006. Aceito em outubro de 2007. ISSN 0073-4721

Artigo disponível em: www.scielo.br/isz 